\title{
Language Learning Strategies (LLSs) and L2 motivation associated with L2 pronunciation development in pre-service teachers of English
}

\author{
Mauricio Véliz C.*
}

\begin{abstract}
This study seeks to uncover the psychosocial mechanisms used by pre-service teachers of English with the purpose of developing an L2 phonological system, within a framework of language learning strategies (LLSs)

The study makes use of a case study methodology and collects information through a semi-structured interview, whose results are interpreted in light of Oxford's (1990) taxonomy. The results corroborate to some extent findings made in previous studies, amongst which are: (i) ample use of indirect strategies, amongst which metacognitive, planning and monitoring stand out; (ii) greater potential of metacognitive strategies when accompanied by use of direct strategies such as mental images, applying images and sounds, practising, analysing/reasoning, and paying attention; and (iii) the mobilisation power of motivation in connection with a strategy repertoire.
\end{abstract}

Key words: Language Learning Strategies (LLSs), Pronunciation Learning Strategies (PLSs), L2 motivation.

\section{Estrategias de Aprendizaje de una Lengua y motivación L2 asociadas al desarrollo de la pronunciación de una L2 en estudiantes de Pedagogía en Inglés}

\section{Resumen}

La presente investigación busca develar los mecanismos sicosociales que utilizan los profesores de inglés de pre-servicio destacados en su desarrollo fonológico en inglés como L2, canalizados a través de estrategias de aprendizaje de una lengua.

La investigación hace uso de la metodología de estudio de caso y recaba información de los dos participantes a través de la entrevista semi-estructurada, cuyos

* $\quad$ BA in Education, MA in Linguistics, EdD (c) TESOL and Education, Universidad Católica Silva Henríquez, mveliz@ucsh.cl 
Language Learning Strategies (LLSs) and L2 motivation associated with L2 pronunciation development in pre-service teachers of English / Mauricio Véliz

resultados son analizados a la luz de la taxonomía propuesta por Oxford (1990). Los resultados corroboran en cierta medida estudios anteriores en los siguientes sentidos: (i) los participantes hacen amplio uso de estrategias indirectas, entre las cuales destacan las estrategias metacognitivas, planificación del aprendizaje y monitoreo; (ii) las estrategias metacognitivas se ven potenciadas cuando entran en contacto con el uso de estrategias directas, tales como la creación de imágenes mentales, aplicación de imagen y sonido, práctica, razonamiento cognitivo y foco atencional; y (iii) la motivación se presenta como variable movilizadora del repertorio de estrategias de aprendizaje.

Palabras clave: Estrategias de Aprendizaje de una Lengua, Estrategias de Aprendizaje de Pronunciación, motivación L2.

Recibido: 30-11-2011Ａceptado: 29-12-2011

\section{Introduction}

This investigation arose from a personal professional concern as I have taught English phonetics and phonology courses at teacher-training college level over the last 15 years or so in Chile. Similarly, the research papers I have written and published correspond to descriptive phonetic studies in the main, especially in the area of suprasegments, which is -rather regrettably- how L2 pronunciation development has been treated, (Jenkins, 2005). In a similar vein, as prominent researchers have recently pointed out, scant work has been done on how sociopsychological factors influence L2 pronunciation development, and by the same token accent attainment, let alone at teacher-training college level (Moyer, 2007; Jenkins, 2005; Derwing and Munro, 2005). The two sociopsychological variables that are closely examined in light of L2 pronunciation development in pre-service teachers of English are motivation and the use of LLSs; hence the ensuing literature review centres on such two major constructs.

The present case study is partly premised on the assumption that what (good) language learners do might provide useful insights into both a better understanding of the multifarious nature of language learning -L2 pronunciation development influenced by motivation and the use of LLSs- and, perhaps, possible applications of principles to pronunciation teaching.

The investigation aims to unearth the specific and individual language strategies used by learners of English at a teacher-training

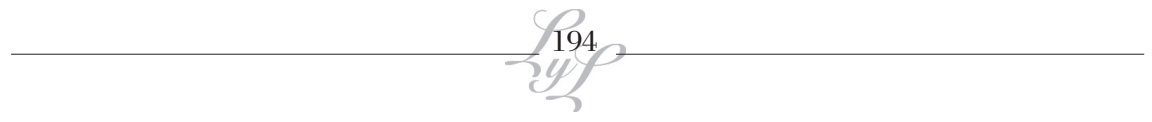


college, who have learned the L2 at a postpubertal stage and have attained a particularly native-like accent, in a foreign language (FL) context. Likewise, the study aims to elucidate how motivation relates to high performance in L2 pronunciation in pre-service English teachers, adopting a fairly broader perspective on motivation, as suggested by Dörnyei (1996). Conversely, the study does not intend to elucidate the possibility and/or applicability of the LLSs used by the respondents in subsequent pronunciation courses, a concern addressed by renowned authors such as Naiman et al. (1978)

The context in which the study is set is one that remains virtually unexplored as far as L2 phonological development is concerned, for this area of study has been primarily addressed in the context of L1 (first language acquisition), which falls outside the domain of this study altogether, or L2, yet employing general English learners at schoollevel, adult general English learners at university level, ESP learners, or immigrant language learners, (Munro and Derwing, 2006; Gatbon et al., 2005; Cenoz and García-Lecumberri, 1999). The peculiarity about the context of this investigation is that participants are pursuing a five-year concurrent English teacher training programme, in an EFL context, where English pronunciation - phonetics rather- takes up considerable space in the curriculum of their major (two and a half years divided up into five semester courses). Thus L2 phonological development comes across as a key component in their training.

Over the last 30 or so years, an attempt has been made to establish commonalities in the behaviours amongst good language learners (GLLs). Such early work (Rubin, 1975; Naiman et al., 1978) rightly asserts what can be thought to be unmistakably apparent: Some learners are more successful than others. Similarly, early investigation intimates that an intricate strategic interplay between cognitive and social processes can be observed in peculiar language learning situations where, for instance, an individual learns an L2 despite the (existence or quality of the) teacher, materials, or environment.

Research has also suggested that such strategic procedures (or language learning strategies, LLSs for short) might differ depending upon a number of variables, such as the language learning macrocontext -whether it is an FL or a second language (SL) context-, (Gu, 1996; LoCastro, 1994); the learner's level (Kimura, 1999); the learner's age (Fleming et al., 1998); specific idiosyncratic features, and such like. Similarly, the role of motivation is still regarded as pivotal in foreign language learning; hence an ensuing discussion is furnished on how 
Language Learning Strategies (LLSs) and L2 motivation associated with L2 pronunciation development in pre-service teachers of English / Mauricio Véliz

motivation relates to language learning in general, with occasional reference to accent attainment.

As for the structure of the study, the key constructs to this investigation, viz. motivation and LLSs are briefly, yet thoroughly treated; later the research design is presented, followed by a description of the data analysis process; lastly, the data analysis and conclusions are furnished.

\subsection{Language learning strategies}

The study of LLSs extends for more than 30 years, yet the actual term probably came into formal existence only in 2004, during the Oxford meeting, where a number of researchers interested in the topic convened (Cohen and Macaro, 2007). Despite the decades of study of LLSs, some of the initial claims still hold true today. As a way of illustration, Rubin (ibid.: 43) argues that 'good language learning' is contingent upon three variables: aptitude, motivation, and opportunity. Rubin also acknowledges the importance of isolating 'what the good learner does -what his strategies are- and impart his knowledge to less successful learners'. Later, she loosely defines strategies as 'techniques or devices which a learner uses to acquire language'. Wenden and Rubin (1987:19) define learning strategies as '... any sets of operations, steps, plans, routines used by the learner to facilitate the obtaining, storage, retrieval, and use of information'. The three major strategies used by good language learners, she contends, are as follows: The GLL may be a (i) good and accurate guesser in that s/he stores and processes information efficiently; (ii) employs whichever means to make himself/ herself understood; and (iii) is constantly experimenting with the newly acquired knowledge. Additionally, she claims that the GLL regularly monitors his/her and others' speech; the GLL practices and 'seeks out opportunities to use the language' (ibid.: 47) and is willing to attend to both form and meaning. Such features are also mentioned by Ellis (1994: 546-549) as significant behaviours capable of facilitating the language learning process.

Stern (1975), as Rubin did as well, offers a list of strategies which by and large stems from the authors' own experience as language learners and/or teachers, but which until then lacked empirical evidence. The 80s saw a fairly fuzzy use of terminology, which in turn evidenced an unclear scope of strategy research, and an equally unclear conceptualization of what strategy really entails. For Wong-Fillmore (1979), strategy was

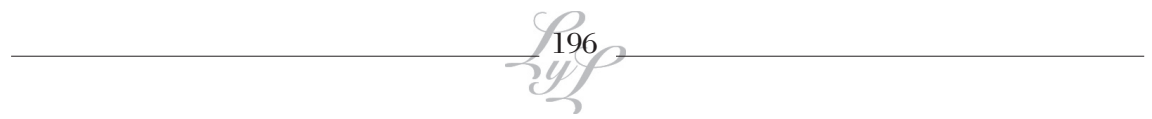


conceived as a relatively broad concept relating to communication in general, whilst for others strategy was to equate 'study skills'.

Regardless of whether one focuses on LLSs, the GLL, or learner autonomy separately, the common ground amongst the aforementioned foci of analysis is the existence of behaviours and/or mental operations that facilitate the language learning process. This is what led Reiss (1981) to posit that the language classroom success depends on the degree of congruence between teaching methodology and students' cognitive type.

It must be noted that for this study the social dimension revolving around the use of LLSs has not been disregarded altogether; indeed, social aspects do crop up in the accounts provided by the participants, especially subject 2. Yet, and perhaps more importantly, LLSs -notwithstanding the stance from which they are theorised- have more often than not been conceptualised as pertaining to the individual. Such transition in the way LLSs moved from a primarily cognitive dimension to one that incorporates a metacognitive and a social dimension can be observed in the work of O'Malley and Chamot (1990), who followed up on the work of Anderson, a cognitive psychologist, and enriched his theory with such incorporations.

The literature presents a fairly ample array of attempts to classify LLSs (Wenden and Rubin 1987; O'Malley et al. 1985; Oxford 1990; Stern 1992; Ellis 1994, amongst others). In this study, I shall follow Oxford's taxonomy (1990), whose classification -broadly speaking-can be divided up into two different macro-types: direct or indirect, where the former encompasses memory, cognitive and compensation strategies, and the latter comprises metacognitive, affective, and social strategies. It must be pointed out, however, that LLSs -together with their ensuing classification- have been largely conceived as oriented towards language competence development in rather holistic terms (ibid.: 8), and not as skill-specific strategies, as is the case of this study. Consequently, the relationship between Oxford's taxonomy and L2 accent development is not altogether a straightforward one.

Broadly speaking, direct strategies 'require mental processing of the language', (ibid.: 37) in slightly different ways, while indirect strategies are those that 'underpin the business of language learning... without (in many instances) directly involving the target language', where metacognitive strategies relate to how learners control their learning process; affective strategies relate to how learners regulate their emotions, 
Language Learning Strategies (LLSs) and L2 motivation associated with L2 pronunciation development in pre-service teachers of English / Mauricio Véliz

motivations and attitudes; and social strategies which relate to how the learner learns through interaction with others.

Here is Oxford's (1990: 17) classification, together with the sub-types and examples of each in italics:

\section{(i) DIRECT STRATEGIES}

1. Memory

A. Creating mental linkages

B. Applying images and sounds

C. Reviewing well

D. Employing action

2. Cognitive

A. Practising

B. Receiving and sending messages strategies

C. Analysing and reasoning

D. Creating structure for input and output

3. Compensation strategies

A. Guessing intelligently

B. Overcoming limitations in speaking and writing

(ii) INDIRECT STRATEGIES

1. Metacognitive Strategies
A. Centering your learning
B. Arranging and planning your learning
C. Evaluating your learning

2. Affective Strategies

A. Lowering your anxiety

B. Encouraging yourself

C. Taking your emotional temperature

3. Social Strategies

A. Asking questions

B. Cooperating with others

C. Emphathising with others

Without doubt, notwithstanding the occasional bitter criticism, one of Oxford's most significant contributions in LLS research is the Strategy Inventory for Language Learning (SILL for short), a questionnaire devised to measure the language learners' frequency of strategy use. Moreover,

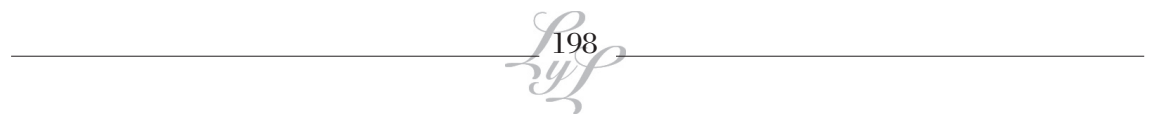


the instrument has been widely used across the world and a number of articles and theses have been written with the instrument at the heart of both the conceptual and methodological schemes.

Another source of either theoretical complementarity or sheer criticism of mainstream LLS research comes from sociocultural theory (SCT), according to which learners' language strategy use is significantly shaped by the environments they find themselves in (Gao, 2006), or -put differently- by the social configuration and participation in class which helps the learner 'to develop, reflect upon, and refine their own language learning strategies', (Donato and McCormick, 1994: 453). Put simply, SCT claims that second language acquisition -LLSs included-is a process that the individual undergoes, not oblivious to the social, but thanks to the social (Lantolf and Thorne, 2006). It has also been suggested that LLSs are constantly subject to change as they are shaped by the everchanging communities L2 learners are immersed in (Gihan, 2002)

Notwithstanding the contributions that SCT can make, this case study reports on LLSs reported by the two participants, which are later categorised employing Oxford's taxonomy. In order to be able to account for the complexities of the social influence on the participants' use of LLSs, different data collection methods are required. Nonetheless, mentions to explicit social strategies are made in light of Oxford's taxonomy.

\subsection{A critique of LLSs}

LLSs have been challenged in different respects: It has been argued, for instance, that the actual application of strategy instruction in order to promote language learning seems limited, let alone in unfavourable conditions such as large classes or simply diverse sociocultural contexts (LoCastro, 1994); also, the fact that much of work on LLSs has resulted from very specific cultural contexts, with equally distinct participants -primarily Canada and immigrants who wish/must learn English-raises questions with regard to the replicability of those findings. LLSs have also been challenged on the basis of an alleged methodological vagueness (Dörnyei, 2005; Macaro, 2006) and the lack of clarity as to whether they constitute 'observable behaviours or inner mental operations, or both', (Tseng et al., 2006: 80)

On a different plane, as Ding (2007: 272) suggests, although the methods traditionally used to uncover LLSs, viz. questionnaires, surveys, reports, observation procedures, amongst others, can easily be 
Language Learning Strategies (LLSs) and L2 motivation associated with L2 pronunciation development in pre-service teachers of English / Mauricio Véliz

critiqued on the basis of their inherent (un-)reliability, the importance of conducting such research lies in the potential it has -as Ellis also (1994) claims- for providing 'good insights into the kinds of behaviour associated with successful language learning'. Similar criticisms of the alleged congruence between learners' verbalisations and actual internal realities have also come from Seliger (1983), Ellis (1986) and Stevick (1990)

Although ample evidence suggesting correlation between GLL's competence progress and use of LLSs has been accumulated in the relevant literature, there is still shaky empirical evidence indicative of LLS use as a causal factor for language learning, as contended by ReesMiller (1993)

Some authors have abandoned the term LLSs and have moved into the term -first coined in cognitive psychology- 'self-regulation'. Metacognitive strategies, however, seem to correspond to what selfregulation implies, i.e. the deployment of 'general skills through which learners manage, direct, regulate [and] guide their learning', (Wenden, 1998: 519, as cited in Gao, 2007:617), which do not solely reflect the actual use of strategies when faced with a particular task, but also more permanent underlying features of the learner.

All in all, the study of LLSs still proves promising and further terra incognita is to be uncovered, especially if such investigation is conducted in FL settings, as is the case of Chile, and focusing on linguistic skills that have not been explored as far as LLS research is concerned.

\subsection{LLSs research}

As stated earlier, much of the formal LLS research has been conducted over the last 30 or so years; at the outset such research was inundated with impressionistic observations, yet over the last 15 years the body of knowledge has become quite solid and some of the early criticisms have been heeded. LoCastro (1994: 410), for instance, examined 'the kinds of effort good or successful Japanese learners of English make to develop their language skills' in fairly large classes and in an FL environment. It was discovered that extrinsic motivation in the form of 'exams' played an important role, together with intrinsic motivation expressed as 'love for the language'. Also, the respondents agree on the extra effort they make, which manifests itself in using the following strategies: 'listening, especially to a radio or TV programmes, or videos, or movies; oral reading; and memorization of grammar and vocabulary'.

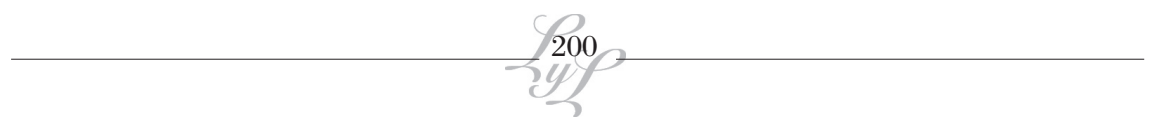


In a similar vein, Fleming et al. (1998) conducted a piece of research which attempted to evidence the strategies that language learners used when asked to perform two learning tasks in normal lesson time, after which the students were interviewed for their use of both cognitive and metacognitive strategies. The results reveal that the respondents made good and ample use of metacognitive strategies, especially in terms of organization and preparation of work; this is accompanied by an awareness of abstract notions of sequencing and structure of work. The language learners studied showed a range of strategies, which -complemented by the higher-order strategies- made them quite autonomous learners.

Takeuchi (2003) conducted a highly comprehensive documentary study by analysing a total of 67 books on how successful learners have learned the L2 in Japan, an FL context. The author read all books for strategies, which were later categorised into pre-established sets. One of the most important commonalities amongst all learners' accounts, 160 in total, is that they had learned the L2 after puberty. The results reveal that metacognitive strategies were profusely used amongst successful L2 learners; such strategies took the form of, for instance, 'maximising opportunities to use the language', pushing oneself into using the language', learning intensively', 'learning regularly', and 'having a plan for learning'. There was recurrent use of time-adverbials such as 'every day', every morning' or 'at least several times a week'. Learners reported to have spent considerable time at the beginning of their learning process doing 'deep listening' and later gradually shifted to 'broad listening'. As for pronunciation proper, GLLs reported to have 'listened to the sounds and prosody...many times, imitated them as perfectly as possible, and then checked the differences between the model and their speech', (Takeuchi, 2003: 388), results which seem compatible with earlier studies Purcell and Suter (1980) and Moyer (1999), where formal training on suprasegments appear to correlate with near-native accent achievement in adult learners. This is accompanied by the use of conscious strategies such as watching the mouth and lips of native speakers, which goes along the lines of conscious efforts made to improve pronunciation as reported by LoCastro (1994)

Lastly, Ding (2007) studied the strategies used by Chinese learners and discovered that (text) memorisation and imitation, preceded by noticing form, are regarded as highly effective strategies. The same applied to pronunciation, wherein learners applied such strategies at increasingly larger units, starting from phonemes, moving onto words, 
Language Learning Strategies (LLSs) and L2 motivation associated with L2 pronunciation development in pre-service teachers of English / Mauricio Véliz

and then sentences. Thus, Ding claims, learners mobilise their initially noticed form from working memory to long-term memory.

As for the strategies and/or factors influencing L2 pronunciation, the scant research done, conducted by phoneticians in the main such as Cenoz and García-Lecumberri (1999), in different contexts and with different English learner types and age-groups from the one represented in this study, suggests that the perceived successful strategies are social contact with native speakers -which confirms previous similar claims (Chryshichoos 1991); and explicit phonetic training in both segments and suprasegments; nonetheless, personal abilities are not regarded as crucial for the acquisition of L2 pronunciation, which collides head-on with previous findings (Suter 1976; Purcell \& Suter 1980; Thompson 1991). Similarly, the participants' previous experiences with different varieties of a language seem to correlate with the perceived degree of difficulty of various accents.

This succinct survey of LLS research exhibits great potential to either be further studied in other contexts or replicated. Indeed, the conclusions in this investigation refer back to some of the findings reported above.

\subsection{L2 Motivation and LLSs}

Motivation research has followed a fruitful trajectory over the last 30 years, notwithstanding the occasional theoretical clashes between SLA and motivation research. Thus motivation as a construct is still regarded as one of the variables upon which, as Rubin (1975) claims, language learning success depends in part. The relevance of linking motivation research and LLSs is premised on the assumption that motivation for the most part takes operational forms, which largely suggest the use of specific LLSs. Indeed, one of most recent research approaches to motivation suggests, as posited by McGroarty (2001) in the main, a three-pronged construct, wherein one of them touches upon the use of LLSs.

Lambert (1972) shifts away from purely cognitive predictors of language learning success such as aptitude and intelligence, both of which were traditionally regarded as fairly stable determinants, and puts forward a twofold scheme of L2 motivation: integrative vs. instrumental. The first one deals with a desire to identify with members of another linguistic-cultural group and be willing to take on very subtle aspects of their behaviour, including their distinctive style of speech and their

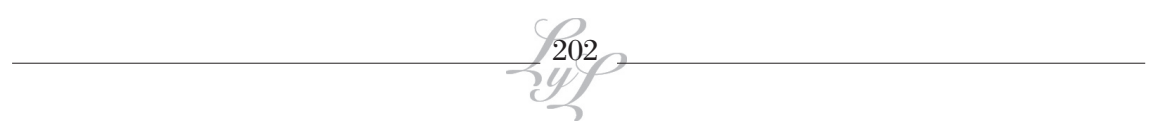


language', (Lambert, 1972: 290), while the second concerns utilitarian purposes associated with L2 learning, with considerably less weight.

Broadly speaking, three major motivation theories have appeared after Lambert's groundbreaking work. From the 80s onwards Deci and Ryan $(1985,2002)$ have developed the so-called self-determination theory, which proposes a complex interplay between extrinsic and intrinsic motivation. Noels (2001a, 2001b) is indeed one of the most prominent figures responsible for the application of this meta-theory in L2, which also addresses how environments, be they controlling or autonomysupportive, contribute to motivation; the applications of this theory can be observed in the study of learner's autonomy, which-yet again-surely translate themselves into specific LLSs evidencing autonomy.

Another theory, mainly developed by Weiner (1992) and applied to language learning by Williams and Burden $(1999,2001)$, and which became an increasingly dominant one in the $80 \mathrm{~s}$ is the so-called attribution theory, according to which our past (linguistic) experiences determine our motivational tendencies. Put differently, depending on the reasons we ascribe past success or failure on a language learning task, we will either feel motivated to perform a given activity or not.

Later in the 90s Tremblay and Gardner (1995) proposed a theory which underscores the importance of goals as a theoretical construct made up of specificity of the learner's goals and the actual use of goalsetting strategies, congruence that may well be applied to L2 learning. McGroarty (2001), on the other hand, proposes a more situated approach to motivation (in L2), wherein the specific context of a learning activity can exert a major motivational influence. This situated approach is threefold: it comprises the study of (i) willingness to communicate; (ii) task motivation; and (iii) the relationship between motivation and LLSs, from a process-oriented perspective which accounts for the 'ongoing changes of motivation over time', (Dörnyei, 2003: 18)

\subsection{The participants}

Both participants, a female (1) and a male (2), are pursuing an English teacher training course at a Santiago-Chile university. Both of them are year 3 students. None of them has yet completed the five-semester English phonetics course and were referred to the researcher by their corresponding phonetics lecturers on the basis on their exceptional performance. More importantly, both participants learned the L2 as a 
Language Learning Strategies (LLSs) and L2 motivation associated with L2 pronunciation development in pre-service teachers of English / Mauricio Véliz

post-pubertal age, which -as the relevant theory suggests-, militates against accent attainment.

\subsection{Paradigm, methodology and method}

The present study incorporates elements of the interpretative paradigm in that, as Cresswell (2003: 8) argues, the researcher relies on the participants' views of the phenomenon studied and thinks of the world as a highly complex and ambiguous reality, where multiple individual realities coexist; as for the research methodology, the case study has been preferred on the following grounds:

Due to the nature of the investigation, wherein very few individuals attain a near native accent in L2 -as the relevant research indicates-, a case study seems highly suitable in that it constitutes 'a specific instance designed to illustrate a more general principle', (Cohen and Manion, 2007: 253). Moreover, a case study seems suitable for the purposes of the present investigation, for 'it presents a unique example of real people in real situations [which]... help[s] readers to understand how ideas and abstract principles fit together'.

Following Yin's classification of case studies (1984), the present investigation shares elements of the exploratory and descriptive types, in that much -if not all! - the work on LLSs has focused on language as a whole, and not on one particular linguistic skill, pronunciation (or accent) attainment in our case; it is descriptive in that it attempts to furnish an explanatory set of mechanisms and behaviours used by the participants, responsible for their successful L2 accent attainment. A case study has been preferred with two subjects who share the features outlined by Thomas (2011) on the grounds that, given the characterisation provided about both subjects, they correspond to what has been termed 'outliers', which presents great potential for insights into the phenomenon the researcher seeks to understand.

As for the method, the semi-structured interview has been preferred, for it enjoys the advantages of both unstructured and structured interviews: It offers more potential for richness of data, which is often associated with the unstructured interview, and it offers a great opportunity to handle the data more easily, without necessarily minimising the possibility to get in-depth perspectives from the interviewees. The language used in the interview was Spanish in order to eradicate any possible linguistic barriers that could obscure the meanings sought with the interview.

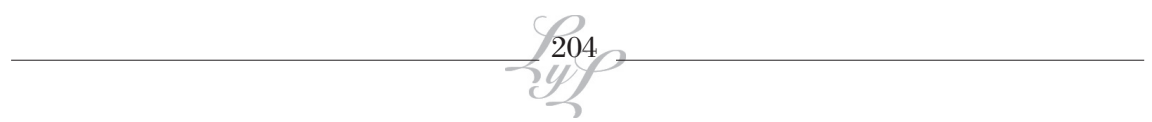


As far as the ethical issues involved in the study are concerned, both participants were duly informed about the nature of the study and the reasons for considering them as potential participants; they were both reassured that the information provided would be used for strictly research purposes. On a slightly different plane, yet of an equally ethical nature, the researcher made use of the technical phonetic features of the English language and combined it with informal accounts of LLSs and motivation in order to provide the participants with a framework and refrained himself from imposing a bias during the interviews.

\subsection{Limitations of the study}

The present case study examines two subjects that meet the requirements for this methodology in that they exhibit peculiar and interesting features which can shed on light on the phenomenon at hand, L2 pronunciation improvement in an EFL context at teacher-training college level. While the researcher has been able to access the participants' views, feelings, attitudes, study routines, and general memories diachronically, the study relies exceedingly heavily on their accounts; in this respect, a longitudinal approach could have rendered the results more accurate and reliable, especially if accompanied with a research tool termed 'oral protocol'.

Case studies have come in for criticism on their alleged inability to draw generalisable conclusions, yet -as Thomas (2011) puts it-if it is a valid for this case, it is valid for many cases.

\subsection{Research questions}

The research questions revolve around the key issues addressed in the study, viz. LLSs (questions (i) - (iii), and motivation (question (iv)).

The research questions are as follows:

(i) (Following Oxford's classification of LLSs) Are direct and indirect LLSs employed for pronunciation improvement?

(ii) What are the main LLSs used by the participants in order to attain a native-like accent?

(iii) To what extent do the LLSs used by the participants relate to formal instruction in L2 pronunciation and phonetics?

(iv) How does motivation relate to the LLSs used by the participants in accent-attainment process? 
Language Learning Strategies (LLSs) and L2 motivation associated with L2 pronunciation development in pre-service teachers of English / Mauricio Véliz

\subsection{Data analysis process}

The interviews were conducted following the recommendations provided in the relevant literature, e.g. (i) requesting informed consent to the respondents, (ii) piloting and grading the questions beginning by non-threatening ones with a view to establishing rapport, while smoothly moving to questions intended to elicit the participants' views, opinions and knowledge about the phenomena at hand; (iii) recording and transcribing the interview orthographically -with some occasional use of phonetic diacritics where key meanings had to be faithfully represented (e.g. use of marking for tones and pauses in the main); (iv) analysis of the data following rigorous iteration procedures of content analysis (e.g. memoing). The whole process of administering the interviews, transcribing them and analysing them took approximately 4 weeks.

As for the data analysis process proper, the following must be pointed out:

- Because of the linguistic nature of the data collected, I transcribed it following some basic conventions of phonemic transcriptions, viz. division of text into intonation groups, identification of nuclear accents in potentially rich utterances, and occasional marking of tones in particular utterances;

- Halfway through the transcription the researcher noticed a high degree of iteration, yet the whole data was eventually transcribed;

- After the whole material was transcribed, the transcription was read with a view to looking for patterns, some of which had become apparent during the transcription phase;

- Content analysis: The patterns found were annotated on the margin using labels that correspond to the core elements contained in the research questions (memoing);

- Finally, a last reading of the transcription -and memos in particularwas carried out with the purpose of clustering patterns together, thus establishing categories for later analysis.

\subsection{Data analysis and presentation of results}

The results for LLS use are succinctly presented in Tables 1 and 2 for subjects 1 and 2, respectively. The results are later discussed around the research questions, a method that corresponds to one of the various

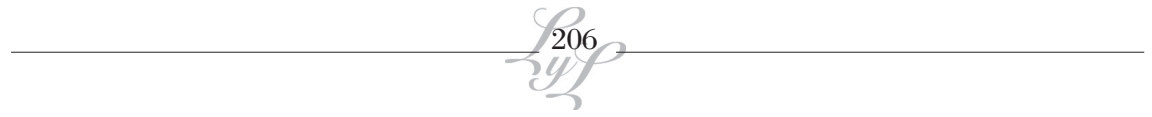


possible formats as Cohen and Manion (2007) suggest. The results for motivation are presented in Table 3. It must be borne in mind that the whole analysis below is presented on the basis of LLSs used specifically for L2 pronunciation enhancement, in conjunction with the role of motivation, contained in research question (iv).

Table 1: subject 1, Direct and Indirect strategies

\begin{tabular}{|c|c|c|}
\hline \multicolumn{3}{|c|}{ Direct strategies } \\
\hline Memory & Cognitive & Compensation \\
\hline $\begin{array}{l}\text { Creates mental images } \\
\text { when listening to English: } \\
\text { mentally visualises phonetic } \\
\text { symbols }\end{array}$ & $\begin{array}{l}\text { Practises pronunciations } \\
\text { and transcriptions } \\
\text { following a well-established } \\
\text { scheme }\end{array}$ & \\
\hline $\begin{array}{l}\text { Contrasts mentally } \\
\text { created phonetic images } \\
\text { with transcriptions and } \\
\text { memorises transcriptions } \\
\text { and pronunciations }\end{array}$ & $\begin{array}{l}\text { Permanently reviews both } \\
\text { phonetic transcriptions and } \\
\text { recordings }\end{array}$ & $\begin{array}{l}\text { Anticipates phonetic mental } \\
\text { images when listening to } \\
\text { unknown pronunciations, } \\
\text { words }\end{array}$ \\
\hline \multicolumn{3}{|c|}{ Indirect strategies } \\
\hline Metacognitive & Affective & Social \\
\hline $\begin{array}{l}\text { Centres, arranges and plans } \\
\text { her learning: establishes } \\
\text { study routines }\end{array}$ & $\begin{array}{l}\text { Encourages herself to } \\
\text { perform well, especially } \\
\text { because of perceived aptitude } \\
\text { and high expectations }\end{array}$ & None \\
\hline \multicolumn{3}{|l|}{$\begin{array}{l}\text { Pays attention to } \\
\text { pronunciation (segments in } \\
\text { particular) when listening } \\
\text { to English }\end{array}$} \\
\hline \multicolumn{3}{|l|}{$\begin{array}{l}\text { Pays close attention to } \\
\text { phonological contexts }\end{array}$} \\
\hline \multicolumn{3}{|l|}{$\begin{array}{l}\text { Relates phonological } \\
\text { entities to graphic } \\
\text { representations }\end{array}$} \\
\hline $\begin{array}{l}\text { Evaluates her pronunciation } \\
\text { permanently: looks herself } \\
\text { in the mirror; judges her } \\
\text { performance and corrects it } \\
\text { if deemed necessary }\end{array}$ & & \\
\hline
\end{tabular}


Language Learning Strategies (LLSs) and L2 motivation associated with L2 pronunciation development in pre-service teachers of English / Mauricio Véliz

Table 2: subject 2, Direct and Indirect strategies

\begin{tabular}{|c|c|c|}
\hline \multicolumn{3}{|c|}{ Direct strategies } \\
\hline Memory & Cognitive & Compensation \\
\hline $\begin{array}{l}\text { Creates mental images } \\
\text { when listening to English: } \\
\text { mentally visualises phonetic } \\
\text { symbols for segments and } \\
\text { prosody }\end{array}$ & $\begin{array}{l}\text { Practises pronunciations } \\
\text { and transcriptions } \\
\text { following a well-established } \\
\text { (experiential) scheme }\end{array}$ & \\
\hline $\begin{array}{l}\text { Contrasts mentally } \\
\text { created phonetic images } \\
\text { with transcriptions and } \\
\text { memorises transcriptions } \\
\text { and pronunciations }\end{array}$ & $\begin{array}{l}\text { Permanently reviews both } \\
\text { phonetic transcriptions and } \\
\text { recordings }\end{array}$ & $\begin{array}{l}\text { Anticipates phonetic mental } \\
\text { images when listening to } \\
\text { unknown pronunciations, } \\
\text { words }\end{array}$ \\
\hline \multicolumn{3}{|c|}{ Indirect strategies } \\
\hline Metacognitive & Affective & Social \\
\hline $\begin{array}{l}\text { Centres, arranges and plans } \\
\text { his learning: establishes } \\
\text { practice routines more } \\
\text { experientially }\end{array}$ & $\begin{array}{l}\text { Encourages himself to } \\
\text { perform well, especially } \\
\text { because of perceived aptitude } \\
\text { and high expectations }\end{array}$ & Talks to passing foreigners \\
\hline $\begin{array}{l}\text { Pays attention to } \\
\text { pronunciation (segments } \\
\text { and suprasegments) when } \\
\text { listening to English }\end{array}$ & & $\begin{array}{l}\text { Asks phonetics lecturers for } \\
\text { assistance / clarification }\end{array}$ \\
\hline $\begin{array}{l}\text { Pays close attention to } \\
\text { phonological phenomena } \\
\text { when listening to English }\end{array}$ & & $\begin{array}{l}\text { Skypes friends overseas } \\
\text { regularly }\end{array}$ \\
\hline $\begin{array}{l}\text { Relates phonological } \\
\text { entities to graphic } \\
\text { representations }\end{array}$ & & $\begin{array}{l}\text { Seeks opportunities to } \\
\text { interact with English } \\
\text { language assistance }\end{array}$ \\
\hline $\begin{array}{l}\text { Evaluates his pronunciation } \\
\text { permanently; judges his } \\
\text { performance and corrects it } \\
\text { if deemed necessary }\end{array}$ & & \\
\hline
\end{tabular}

Table 3: Motivation

\begin{tabular}{|l|l|l|l|l|}
\hline \multicolumn{1}{|c|}{} & \multicolumn{1}{|c|}{$\begin{array}{l}\text { Integrative } \\
\text { motivation }\end{array}$} & $\begin{array}{l}\text { Instrumental } \\
\text { motivation }\end{array}$ & $\begin{array}{c}\text { Self- } \\
\text { determination }\end{array}$ & Attribution \\
\hline Subject 1 & $\begin{array}{l}\text { Interest in } \\
\text { pronunciation and in } \\
\text { achieving a near- } \\
\text { native accent appears } \\
\text { even prior to entry to } \\
\text { enrolling in English } \\
\text { teacher training } \\
\text { programme }\end{array}$ & $\begin{array}{l}\text { Regards } \\
\text { pronunciation } \\
\text { as crucial to } \\
\text { the English } \\
\text { teaching } \\
\text { profession }\end{array}$ & $\begin{array}{l}\text { Studied } \\
\text { pronunciation } \\
\text { book following } \\
\text { a self-imposed } \\
\text { structured } \\
\text { organisation } \\
\text { prior to } \\
\text { university }\end{array}$ & $\begin{array}{l}\text { Motivated to } \\
\text { reach high } \\
\text { performance } \\
\text { levels partly } \\
\text { triggered by } \\
\text { perceived } \\
\text { aptitude and } \\
\text { other people's } \\
\text { expectations }\end{array}$ \\
\hline
\end{tabular}

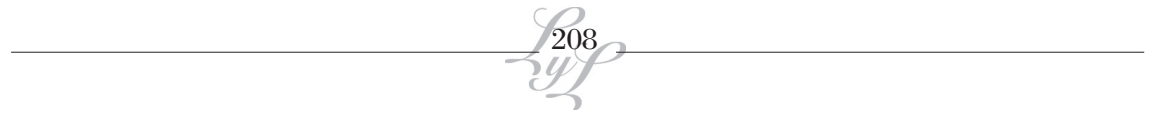




\begin{tabular}{|c|c|c|c|c|}
\hline & $\begin{array}{l}\text { Interest in } \\
\text { pronunciation and in } \\
\text { achieving a near native } \\
\text { accent comes, for the } \\
\text { most part, from 'deep } \\
\text { inside' }\end{array}$ & $\begin{array}{l}\text { Not exhibiting } \\
\text { a very good } \\
\text { pronunciation } \\
\text { in English as } \\
\text { a teacher is } \\
\text { regarded as } \\
\text { 'mediocre' }\end{array}$ & \begin{tabular}{|l|} 
Has developed \\
well-structured \\
study \\
routines and \\
metacognitive \\
strategies
\end{tabular} & \\
\hline & & & $\begin{array}{l}\text { Implements } \\
\text { such } \\
\text { strategies and } \\
\text { procedures } \\
\text { rigorously } \\
\end{array}$ & \\
\hline \multicolumn{5}{|l|}{ Subject 2} \\
\hline & $\begin{array}{l}\text { Interest in } \\
\text { pronunciation and in } \\
\text { achieving a near- } \\
\text { native accent appears } \\
\text { even prior to entry to } \\
\text { enrolling in English } \\
\text { teacher training } \\
\text { programme }\end{array}$ & None & \begin{tabular}{|l|} 
Has developed \\
well-structured \\
study \\
routines and \\
metacognitive \\
strategies
\end{tabular} & $\begin{array}{l}\text { Motivated to } \\
\text { reach high } \\
\text { performance } \\
\text { levels partly } \\
\text { triggered by } \\
\text { perceived } \\
\text { aptitude and } \\
\text { other people's } \\
\text { expectations }\end{array}$ \\
\hline & $\begin{array}{l}\text { Interest in pronunciation } \\
\text { and in achieving a near } \\
\text { native accent comes, for } \\
\text { the most part, from 'deep } \\
\text { inside' }\end{array}$ & & $\begin{array}{l}\text { Implements } \\
\text { such } \\
\text { strategies and } \\
\text { procedures } \\
\text { rigorously }\end{array}$ & \\
\hline & $\begin{array}{l}\text { Reports to 'live' the } \\
\text { language every day; } \\
\text { speaks the language to } \\
\text { his younger sister; talks } \\
\text { to himself I English }\end{array}$ & & & \\
\hline & $\begin{array}{l}\text { Speaking with a British } \\
\text { accent makes him feel } \\
\text { closer to the target } \\
\text { culture }\end{array}$ & & & \\
\hline
\end{tabular}

\subsection{Are direct and indirect LLSs employed for pronunciation improvement? And, what are the main LLSs used by the participants in order to attain a native-like accent?}

Both subjects report on the use of both macro-types of LLSs, yet slight differences can be observed in the extent of use of each. Participant 2 makes considerable use of social strategies, a sub-type of indirect strategies, compared to participant 1 ; subject 2 has always sought to interact with foreigners, particularly 'native' English speakers; he evidences an 
Language Learning Strategies (LLSs) and L2 motivation associated with L2 pronunciation development in pre-service teachers of English / Mauricio Véliz

eagerness to establish oral interaction with foreigners which manifests itself in a 'perceived necessity to approach foreigners on the street and offer assistance, which brings [him] immense satisfaction'. In a similar vein, he remarks that -when in doubt regarding pronunciation- 'he turns to his lecturers, [native] friends on Skype or the [English] language assistant'. Yet, all in all, subject 2 asserts that the work that pronunciation enhancement entails is largely of a personal nature. Participant 1 , on the other hand, seems to make much less use of social strategies, a sub-type of indirect strategies, in that she reports not to have any native English friends; nor does she speak to the British language assistant working for the course she is on. She even ventures to claim that 'about 60\% of the work done in order to achieve [her] current pronunciation level corresponds to [her] individual endeavour'. Seemingly, the subject's personality structure, which corresponds to somebody very much to herself, combined with personal woes she is faced with lead on to an underuse of social strategies. Indeed, it is interesting to observe that the word 'embarrassment' recurs a couple of times, with regard to the use of social strategies; indeed, subject 2 points out that she 'prefers to keep a low profile'.

As for affective strategies, a sub-type of indirect strategies as well, it can be observed that they are the least used in a systematic fashion. Nonetheless, subject 1 reports that her performance can be somewhat affected by her emotional disposition. Both participants express a strong sense of awareness of their perceived aptitude and potential, yet they admit that due to high expectations raised about their performance, they feel further pressurised. It can be inferred, then, that both subjects do encourage themselves to perform well based on their aptitude and their own personal (high) expectations.

By far, the indirect strategies that come across as most widely used by both participants are the metacognitive ones. Both participants seem to employ strategies wherein they centre, arrange and plan their learning. As a way of illustration, participant 1 points out that before she got a place at university, she 'studied a beginner's pronunciation book of [her] own accord and organised [her] work in such a way that that [she] studied two chapters daily, which corresponded to the treatment of one segment a day; [she] would listen to the lesson, the sounds in context, and then repeat'. Subject 1 remarks that as part of all the previous pronunciation and phonetics courses, she would always 'allocate some time for personal study, while now it is only weekends; [she] downloads pronunciation programmes, does phonemic transcription work, practices reading

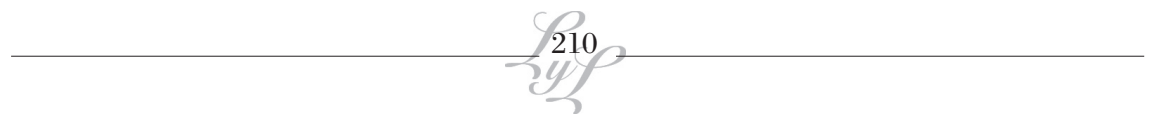


passages, until [she] gets it right'. Participant 2 does not evidence exactly the same organisation and planning strategies, yet he does evince a more experiential organization, for he 'experiences the language routinely: [he] lives [his] life in English; [he] teaches English to her younger sister and speaks to her in English as an everyday activity'. The experiential approach of subject 2 does not mean that no planning or organisation is present; on the contrary, he exhibits a relatively fixed routine to go about the pronunciation of unknown words, which involves hypothesising the pronunciation, consulting a monolingual dictionary first, then a pronunciation dictionary; later [he] searches for contextualised use of the word on YouTube and finally repeats the word in context'. Such a routine implies a somewhat less structured organisation, yet a highly intensive one.

Closely related with this is the strategy of paying attention. In effect, both subjects evince a strong sense of metacognition, which manifests itself in various ways/strategies. As a way of illustration, subject 1 remarks: 'when I watch television, I pay particular attention to pronunciation and lexis; I see [phonetic] symbols in my head. The same happens when I hear a word: I visualise its phonetic transcription and then I practise it until I feel I get it right'. In a similar vein, when asked to give advice on how to improve English pronunciation, wherein the assumption is that such advice reflects the subject's own strategies, subject 1 suggests 'practising a great deal, first in isolation and then at sentence level; the sentence should be practised in smaller chunks, until you get the whole sentence right'. Subject 2 suggests using the pronunciation dictionary, contextualising the pronunciation found (and intensively practised as mentioned earlier), using and practising the pronunciation in context, paying particular attention to both segments and prosody.

As can be observed, paying attention comes across as a widely used strategy, which takes diverse forms. On the one hand, direct paying attention to the core elements which constitute the pronunciation of a language, segments (and suprasegments, in case of subject 2); yet, not only do subjects pay particular attention to the constitutive elements, but also to how they phonologically relate to each other. In such a (selfregulated) reflective and analytical process, subject 1 moves on to remark that '[she] realised the difference between the voiced alveolar plosive and the voiced dental fricative on her own', by paying close attention to the actual articulation of such segments. Paying attention, as can be seen, transcends the actual mental concentration on specific objects; it does imply such concentration on (supra-) segments, yet this seems 
Language Learning Strategies (LLSs) and L2 motivation associated with L2 pronunciation development in pre-service teachers of English / Mauricio Véliz

only a starting point as the subjects report that they relate the features they identify in such objects and relate them to their graphic correlates (phonetic symbols) or vice versa, and more importantly, to the auditory and articulatory correlates. Indeed, the use of such metacognitive strategies becomes void of actual meaning and usefulness if treated in isolation; they appear to become powerful strategies when accompanied by the use of direct strategies such as creating mental images, applying images and sounds, practising, and analysing / reasoning, which are part of the so-called memory strategies.

It must also be pointed out that both subjects seem to make intensive use of the evaluating your learning strategy, a metacognitive strategy. Subject 1 reports that she used to practise segments in isolation and then in context looking herself in the mirror, in order to assess her performance; likewise, she has become the (expert) judge when determining whether the expected pronunciation has been achieved, especially when she goes over her practice routine 'until she gets it right'. The same can be observed in subject 2. Similarly, they both regard themselves as highly critical and fully aware of their own pronunciation output and mistakes.

As can be inferred from above, considerable use of direct strategies accompanies that of indirect strategies, especially metacognitive ones. Within the subtypes of direct strategies, both subjects report that when paying attention to (supra-) segments, they create mental images of the (phonetic) symbols the auditory input relates to. Such images are then contrasted with the phonetic transcription they see whenever in doubt with regard to the pronunciation of a word. Subsequently, a complex mental linkage is established amongst the elements that are foregrounded in the individual's consciousness mediated by analytical procedures. Such a process is followed, in both subjects, by rigorous self-imposed routines of repetition (practising) and review. The subtype that comes across as least used is that of compensation strategies, possibly because they do not relate very closely to pronunciation enhancement.

\subsection{To what extent do the LLSs used by the participants relate to formal instruction in L2 pronunciation and phonetics?}

The strategies described and characterised above relate very closely to the formal instruction they have received, particularly in pronunciation development. As a way of illustration, the use of direct strategies in the form of memory strategies seems intensive in that the subjects report

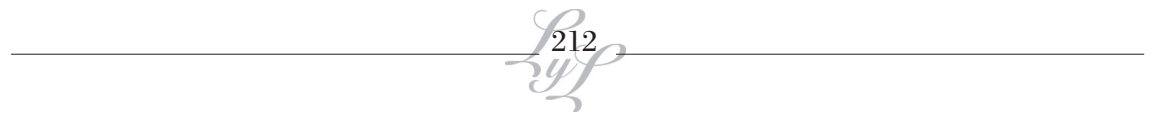


that they have a good visual and auditory memory which they use(d) intensively when they learned the phonetic symbols, or when they hear a word whose pronunciation they look up in a pronunciation dictionary, or when they contrast what they have previously memorised -either graphically or auditorily- with the other corresponding mode of pronunciation (re)presentation, which may encompass rememorizing pronunciation. They both report to 'pay attention to the pronunciation, anticipate a principled guess of the sounds [they] hear, and contrast it with the form provided by the pronunciation dictionary'. Likewise, the creation of mental linkages is equally relevant to the instruction they formally receive as the they link entities that make up the core elements of formal phonetic training, viz. phonetic symbols, segments, suprasegments, auditory stimuli, when they 'see visualise the pronunciation of a new word', as they put it. The same applies to the reported practice and analysis the subjects carry out. In other words, what they practise and analyse is precisely the entities mentioned above, enriched by strategies they have developed autonomously. Also, the value both participants place on phonetic transcriptions is yet another manifestation of how closely related LLSs are to their formal training. Both participants report an intensive use of such a strategy, which can seemingly become a powerful one once advanced L2 students have been able to successfully link the phonetic properties of a segment, with the auditory stimulus and their graphic representation.

Certainly, some of the strategies used by the participants can well be used in the development of other linguistic skills, e.g. creating mental images, reviewing (memory strategies); practising, analysing and reasoning (cognitive strategies); centring your learning, arranging and planning your learning, and evaluating your learning (metacognitive strategies), yet the entities such LLSs relate to are mostly of a phonetic nature.

\subsection{How does motivation relate to the LLSs used by the participants in accent-attainment process?}

Motivation certainly comes across a key complementary variable that seemingly mobilises the intricate interplay of strategies expounded earlier. Following Lambert (1972), both participants evidence 'an interest [in pronunciation enhancement] that comes from deep inside' of them, which originates prior to their university English teacher preparation course (see accounts above); indeed, they both associate an excellent English pronunciation with greater proximity to the target culture. Also, 
Language Learning Strategies (LLSs) and L2 motivation associated with L2 pronunciation development in pre-service teachers of English / Mauricio Véliz

such high levels of integrative motivation are complemented with a high level of perfectionism in both cases; subject 2 remarks: 'since very early in life I have pursued a near-native pronunciation, a pursuit I look upon as a personal duty'. Subject 1 incorporates an element of instrumental motivation as she believes that 'a teacher of English must exhibit a very good pronunciation and [she] does not wish to become a teacher with a mediocre pronunciation'. Such a desire can certainly be interpreted as motivation in the form of setting language goals.

Motivation, in the form of self-determination and autonomy, is clearly evinced in both participants: While in a few cases they have developed slightly different strategies, yet of the same subtypes, the same degree of autonomy can be observed. For instance, subject 1 decided to systematically study a pronunciation book in a highly structured fashion of her own accord, while subject 2 complements his rigorous listening for pronunciation (and language) strategy with the use of YouTube and friends over Skype for contextualised use. Also, both participants' motivational tendencies seem to have been positively affected by the perceived success they exhibited when addressing the pronunciation tasks they embarked upon. Thus a positive past experience gives rise to an apparent increasing level of motivation, which in turn positively affects the use of LLSs.

\subsection{Conclusions}

Although this work differs greatly from much of the LLS research in that it addresses the strategies used to develop one particular skill (L2 accent), many a commonality are found when compared to previous work: A good deal of 'extra work' is involved, wherein listening and memorisation stand out (LoCastro, 1994); ample use of metacognitive strategies, evidencing autonomy, as reported by Fleming et al. (1998); listening, imitation, and checking pronunciation are also present, as reported by Takeuchi (2003), which goes along the lines of what Ding (2007) presents: noticing form (paying attention in this work), memorisation and imitation.

The indirect strategies that come across as most widely used by both participants are the metacognitive ones, where both participants seem to use strategies wherein they centre, arrange and plan their learning. Similarly, both subjects seem to make intensive use of the evaluating your learning strategy, a metacognitive strategy. Yet, the use of such metacognitive strategies becomes void of actual meaning and usefulness

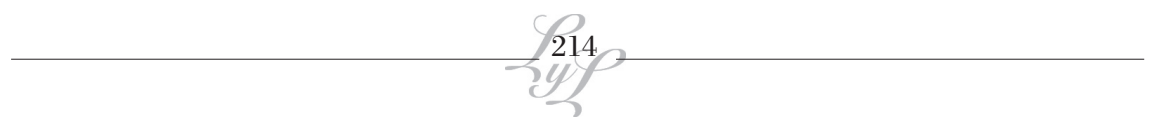


if treated in isolation; they appear to become powerful strategies when accompanied by the use of direct strategies such as creating mental images, applying images and sounds, practising, and analysing/reasoning, which are part of the so-called memory strategies. One of the direct strategies that is more widely used by both subjects is paying attention, which takes diverse forms: Direct paying attention to the core elements which constitute the pronunciation of a language, segments (and suprasegments, in case of subject 2) and also to how they phonologically relate to each other

The strategies expounded above relate very closely to the formal instruction they have received, particularly in pronunciation development. However, it remains unclear whether prosodic training has the high value Moyer (1999) suggests.

It can be safely pointed out that the level of commonality with regard to both which strategies are used by both participants and the intensity of use is remarkably high. The commonality between both subjects is also evidenced in terms of which strategies are least used -or not used at all- by the subjects. Amongst such strategies are some social strategies like cooperating with others, empathising with others; and compensation strategies like guessing, overcoming limitations. This may either suggest a sheer coincidence between the subjects' choice of strategies and extent of use of such strategies or that the nature of the skill and high performance levels expected require the use of strategies reported.

Motivation, regardless of the school of thought is followed, certainly comes across a key complementary variable that seemingly mobilises the intricate interplay of learning strategies.

\section{References}

Cenoz, J. and García Lecumberri, M. L. (1999). The acquisition of English pronunciation: Learners' views. International journal of Applied Linguistics, 9, (1), 3-17.

Cohen, A. and Macaro, E. (2007). Language learner strategies: 30 Years of Research and Practice. Oxford: Oxford University Press.

Cohen, L., \& Manion, L. (2007). Research methods in education. (6th ed.) London: Routledge.

Creswell, J. (2003). Research design: Qualitative, quantitative, and mixed 
Language Learning Strategies (LLSs) and L2 motivation associated with L2 pronunciation development in pre-service teachers of English / Mauricio Véliz

methods approaches. Thousand Oaks, CA: Sage Publications.

Chryshochoos,N. (1991). Learners' awareness of their learning. In C. James. and P. Garret (eds), Language awareness in the classroom (pp.148-62). London: Panton.

Derwing, T. and Munro, M. (2005). Second language accent and pronunciation teaching: A research-based approach. TESOL Quarterly, 39, 379-397

Deci, E. L. and Ryan, R. M. (1985). Intrinsic motivation and self-determination in human behaviour. New York: Plenum.

and _____ (2002). Handbook of self-determination. Rochester: University of Rochester Press.

Ding, Y. (2007). Text memorization and imitation: The practices of successful Chinese learners of English. System, 35, 271-280.

Donato, R. and MacCormick, D. (1994). A Sociocultural Perspective on Language Learning Strategies: The Role of Mediation. The Modern Language Journal, 78, (4), 453-464.

Dörnyei, Z. (1996). Moving language learning motivation to a larger platform for theory and practice. In Oxford, R. (ed.), Language learning motivation: Pathways to the new century. (7180). Honolulu: University of Hawai'I Press.

(2005). The psychology of the language learner: individual differences in second language acquisition. Mahwah, NJ: Erlbaum.

Ellis, R. (1986). Understanding second language acquisition. Oxford: Oxford University Press.

(1994). The study of second language acquisition. Oxford: Oxford University Press.

Fleming, Fay and Walls, Geoff (1998). What pupils do: the role of strategic planning in modern foreign language learning. Language Learning Journal, 18, (1), 14- 21.

Gao, X. (2006). Understanding changes in Chinese students' uses of learning strategies in China and Britain: A socio-cultural reinterpretation. System, 34, 55-67.

(2007). Has language learning strategy research come to an end? A response to Tseng et al. (2006). Applied Linguistics, 28, (4), 615-620.

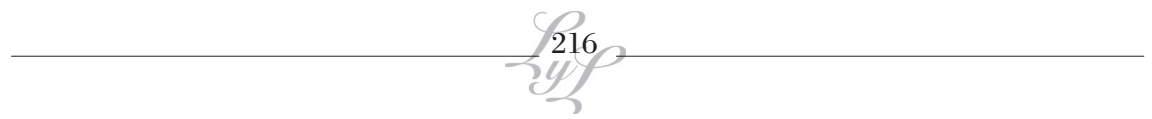


Gatbon, E., Trofimovivh, P., and Magid, M. (2005). Learners' ethnic group affiliation and L2 pronunciation accuracy: A sociolinguistic investigation. TESOL Quarterly, 39, (3), 489-511.

Gihan Sidky Al Azab, Same students, different strategies. A sociocultural perspective to studying language learning strategies in a second language setting (January 1, 2002). Electronic Doctoral Dissertations for UMass Amherst. Paper AAI3068531. http://scholarworks.umass.edu/ dissertations/AAI3068531

Gu, P. Y. (1996). Robin Hood in SLA: what has the learner strategy research taught us? Asian Journal of English Language Teaching, $6,1-21$.

Jenkins, J. (2005). State-of-the-art review article. Language Teaching, 38, $1-17$.

Jones et al. (1987). Strategic teaching and learning: cognitive instruction in the content areas. Alexandria, VA: Association for Supervision and Curriculum Development.

Kimura, M. (1999). Language learning strategies: recent research and applications. A paper presented at the Symposium on Strategy Research in the $12^{\text {th }}$ World Congress of Applied Linguistics, Tokyo, Japan.

Lambert, W. (1972). Language, psychology and culture. Stanford: Stanford University Press.

Lantolf, J., \& Thorne, S. L. (2006). Sociocultural Theory and the Genesis of Second Language Development. Oxford: Oxford University Press.

Lecumberri, M. L. and Gallardo, F. (2003). English FL Sounds in Scool Learners of Different Ages. In Gracía-Mayo, M. del Pilar and García-Lecumberri, M. L. (eds.), Age and the acquisition of English as a foreign language. (pp. 115135). Clevedon: Multilingual Matters Ltd.

LoCastro, V. (1994). Learning Strategies and learning Environments. Brief reports and summaries. TESOL Quarterly, 28, (2), 409-414.

Long, M. (1990). Maturational constraints on language development. Studies in Second language Acquisition, 12, 251-285. 
Language Learning Strategies (LLSs) and L2 motivation associated with L2 pronunciation development in pre-service teachers of English / Mauricio Véliz

Macaro, E. (2006). Strategies for language learning and for language use: revising the theoretical framework. Modern Language Journal, 90, (3), 320-337.

Marinova-Todd, Stefka H.; Marshall, D. Bradford; Snow, Catherine E. (2000). Three misconceptions about age and L2 learning. TESOL Quarterly, 34, (1), 9-34.

McGroarty, M. (2001). Situating second language motivation. In Dörnyei, Z. and Schmidt, R. (eds.), Motivation and second language learning. (69-90). Honolulu, HI: University of Hawai'i Press.

Moyer, A. (1999). Ultimate attainment in L2 phonology. Studies in Second Language Acquisition, 21, 81-108.

(2007). Do language attitudes determine accent? A study of bilinguals in the USA. Journal of Multilingual and Multicultural Development, 28, (6), 502-518.

Munro, M. and Derwing, T. (2006). The functional load principle in ESL pronunciation instruction: An exploratory study. System, 34, 520-531.

Naiman et al. (1978). The good language learner. Toronto: Institute of Studies for Education.

Noels, K. A. (2001a). New orientations in language learning motivation: towards a model of intrinsic, extrinsic, and integrative orientations and motivation. In Dörnyei, Z. and Schmidt, R. (eds.), Motivation and second language learning. (43-68). Honolulu, HI: University of Hawai'i Press.

(2001b). Learning Spanish as a second language: learners' orientations and perceptions of their teachers' communication style. Language Learning, 51, 107-144.

O'Malley et al. (1985). Learning strategy applications with students of English as a second language. TESOL Quarterly, 19, 557-584.

and Chamot, A. U. (1990). Learning strategies in second language acquisition. Cambridge: Cambridge University Press.

Oxford, R. (1990). Language learning strategies: what every teacher should know. Boston, MA: Heinle \& Heinle.

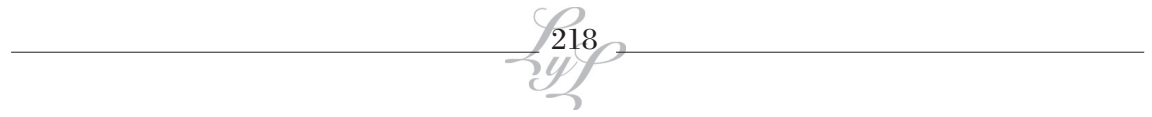


(2001). Language Learning Styles and Strategies. In Celce-Murcia, M. (ed.), Teaching English as a second or foreign language. (359-366). Boston. MA: Heinle \& Heinle.

Penfield, W. and Roberts L. (1959). Speech and Brain Mechanisms. Princeton: Princeton University Press.

Purcell, E. and Suter, R. (1980). Predictors of pronunciation accuracy. A re-examination. Language Learning, 30, 271-287.

Rees-Miller, J. (1993). A critical appraisal of learner learning: theoretical bases and teaching implications. TESOL Quarterly, 27, (4), 679-689.

Reiss, M. A. (1981). Helping the unsuccessful language learner. Modern Language Journal, 65, 121-128.

Rubin, J. (1975). What the "Good learner" can teach us. TESOL Quarterly, 9, (1), 41-51.

Scovel, T. (1988). A time to speak: A Psycholinguistic inquiry into the critical period for human language. Rowley, MA: Newbury House.

Seliger, H. W. (1983). The language learner as linguist: of metaphors and realities. Applied Linguistics, 4, (3), 179-191.

Singleton, D. (2003). Critical Period or General Age Factor(s)?. In GracíaMayo, M. del Pilar and García-Lecumberri, M. L. (eds.), Age and the acquisition of English as a foreign language. (pp. 3-22). Clevedon: Multilingual Matters Ltd.

Stern, H. H. (1975). What can we learn from the good language learner? Canadian Modern Language Review, 31, 304-318.

(1992). Issues and Options in Language Teaching. Oxford: Oxford University Press.

Stevick, E. W. (1990). Research on what? Some terminology. Modern Language Journal, 74, (2), 143-153.

Suter, R. W. (1976). Predictors of pronunciation accuracy in second language learning. Language Learning, 26, 233-53.

Takeuchi, O. (2003). What can we learn from good foreign language learners? A qualitative study in the Japanese foreign language context. System, 31, 385-392.

Thomas, G. (2011). How to do your case study: A guide for students and researchers. Thousand Oaks: Sage. 
Language Learning Strategies (LLSs) and L2 motivation associated with L2 pronunciation development in pre-service teachers of English / Mauricio Véliz

Thompson, I. (1991). Foreign accents revisited: the Enghsh pronunciation of Russian immigrants. Language Learning, 41, 177204.

Tremblay, P. F. and Gardner, R. (1995). Expanding the motivation construct in language learning. Modern Language Journal, 79, 505-518.

Tseng et al. (2006). A new approach to assessing strategic learning: the case of self-regulation in vocabulary acquisition. Applied Linguistics, 27, 78-102.

Weiner, B. (1992). Human motivation: metaphors, theories and research. Newbury Park, CA: Sage.

Wenden, A. and Rubin, J. (1987). Learner Strategies in Language Learning. New Jersey: Prentice Hall.

Williams, M. et al. (2001). Making sense of success and failure: the role of the individual in motivation theory. In Dörnyei, $\mathrm{Z}$. and Schmidt, R. (eds.), Motivation and second language learning. (173-186). Honolulu, HI: University of Hawai'i Press.

and Burden, R. L. (1999). Students' developing conceptions of themselves as language learners. Modern Language Journal, 83, 193-201.

Wong-Fillmore, L. (1979). Individual differences in second language acquisition. In Fillmore, C. J. et al. (eds.), Individual Differences in Language Ability and Language Behavior. (203-228). New York: Academic Press.

Yin, R. (1984). Case study research: Design and methods. Beverly Hills, CA: Sage Publishing. 